\title{
KJERLIGHEDENS GJERNINGER
}

\section{Peter Rønnov-Jessen}

I det yderste Hiørne af Bevidstheden flaxe sorte Flagermuus om, Ecchoer fra en endnu ikke conciperet Fremtid, Skimmelsvamp paa den forlængede Marv.

I denne bygning udbreede Fugerne sig paa Mursteenenes Bekostning, ingen Svale har bygget Rede i Hulrummene og derved marqueret det beboelige Aspect.

Udenfor denne Bygning, paa en brun og muddret Vei, ligge Liigene i Bunker. To Færdsels-Betjente paa Cycler skyde med Skarpt efter uforfærdede Partisaner. Brede Colonner af Motor-Kjøretøier med hvide Flag trænge igjennem den blodige Dynge

Om Taarnets Skyde-Huller svirre frygtløse Flagermuus, deres Skrig uhørlige for det menneskelige Øre, deres Ansigter DødningeMasker fra Spøg- og Skjemt-Boutiquer som forlængst har maattet lukke. En Stank af sødt Blod kryddrer Beskuerens Næse og Gahne.

Et tilfældigt henkastet Qvinde-Cadaver bloquerer for Indkjørselen til Slottet. Jeg faaer ingen Blod paa Hænderne. Den automatiske Pilot fører mig i den trygge Havn.

Baronessen bød Velkommen i sin mugne Spisesal, jeg tog med Henrykkelse mod Tilbudet og bænkede mig ved hendes grovt tilhugne Bord.

Aa hvilken Overdaadighed! Hjerne i egen Saft, dertil en tør Spinal-Prøve, og. jeg tilstaaer strax: Qvaliteten fristede ikke Gour- 
met'en til at sende Skallen tilbage! Min charmante Vertinde kurrede under Spisningen.

Jeg græder meget i denne Tid. Mit Uhr er gaaet istaae.

Og efter Middagen: de let adskilte Læber, den svimle Puls, den befriende Søvn

Jeg kastede op og aad mit eget Bræk.

Lystige Park-Betjente skøde til Maals efter Børnene, smilende saae

C jeg og min Vertinde til.

Der er Svamp i Etage-Adskillelserne.

Flagermuusene skrige med Barnestemmer. Jeg tager endnu et Glas.

Min Vogn brød sammen, og jeg søgte Tilflugt paa Slottet.

Slotsfruen tog venligt imod mig, vi talede til langt ud paa Natten om de seneste Begivenheder paa Egnen. Siden gik vi i Seng. Hun skreeg høit og længe. Hende Aande var beesk.

Flagermuusene have Børns Ansigter. Mit Uhr gik istaae, og jeg brast i Graad. Flagermuusenes Skrig ere uhørlige.

Dette Huus er fuldt af Svamp. Stretococci mase dem ind i Rygmarven. De tage deer Kampen op med virile Spirochætæ.

Baronessen tømmer endnu en Skaal. Min Vogn bliver imedens tilseet af den mordlystne Gartner, hans Kniv er stadig blodig.

Qvinden, som kom i Veien for min Vogn, er stadig ikke identificeret. Dog kommer det mig for at jeg skulde kjende hende.

Flagermuusens Aande er ram og sød. Jeg græder i min Uhr-Kasse. Jeg har ingen Appetit.

Denne Egn er kjendt for sine Borgeres patriotiske Sindelag. De udmærke dem ved at have erhvervet uforholdsmæssigt mange Medailler i Krigene. Her ere ingen Mindes-Mærker, Huusene holdes kun daarligt. Jeg seer brune Mursteens-Mure, faldefærdige. Ingen Svaler har slaaet Leier deer.

Jeg kommer her jevnlig og rider lange Toure med min Veninde, Baronessen. Paa Agrene seer man ofte Spor af natlige Batailler. Om Dagen seer man ingen Flagermuus, som Omegnen ellers er saa riig paa. De optræde kun efter Mørkets Frembrud. Deres Øine ere Knappenaals-Hoveder i skrumpne Barneansigter. Min Vertindes Latter viser Vei over afsvedne Marker, Hestenes Flanker ere svedige og blodige. Det skambidte Qvæg skrige ikke længer, under Træerne beundrer jeg min Venindes Skuldre. Park-Betjentene meddeele os at to Partisaner ere tagne tilfange, Baronessens Lettelse er intents. Den lille Lund seer forfalden ud, dens Træer have ikke modtaget den rette Vedligeholdelse. Min Venindes Brystvorter stritte som smaae Torpedoer langs Steen-Gjerdet.
Vi nødsages desværre til at ombringe den ene Hest, den jeg har redet paa. Jeg lukker Øinene idet jeg krummer Fingeren om Aftræk-

To Gendarmer fra den nærliggende Landsby ankomme til Slottet. De meddele os intet afgjørende Nyt. Endnu en Stilling er falden, seer det ud til, men Communications-Linierne ere ikke paalidelige.

Paa Reisen græd jeg en Deel. Mit Uhr, som havde stor AffectionsVærdi for mig, var gaaet itu. Baronessen overtalede mig til at kaste den ubrugelige Gjenstand bort, og siden er det gaaet mig meget bedre. Vi leer meget sammen. Hendes Stemme er dyb og knurrende. Paa indersiden af det høire Laar, lige under Skjødet, har hun en liden Skjønheds-Plet. Flagermuusene ere ualmindelig velvoxne i Aar. Min Vertinde taler flaxende om eventuelle Restaurationer af Murværket, men det har hun altid gjort, det er aldrig blevet til Noget. Jeg drikker hendes Skaal og kjeler for hendes Knæ. Hendes Skjønhed er ubestridelig.

Jeg kan kun daarligt opfatte min Venindes Skrig, men hendes Orienterings-Sands lader Intet tilbage at ønske. Mit Uhr ligner et Barneansigt, jeg faaer Øie paa det i Papir-Kurven. Det græder ingenlunde. I Gulvet, fortæller man mig, er der Svamp. Jeg maa ikke træde udenfor Afmærkningerne. Fogeden fortæller mig at den megen Uro paa Egnen snart er ganske nedkjæmpet. Baronessen kalder paa mig, og vi tilbringer en angeneem Aften i interessant Conversation.

Jeg veed ikke om min Vertinde bader i Flagermuusenes blod. Men en vis poetisk Retfærdighed maa der da være til.

Om Natten: Baronessens Hud er blød som Silke!

Hvis jeg havde havt en hurtigere Vogn, vilde jeg have kunnet komme megèt tidligere. Underveis havde jeg det konstigste Uheld: en Qvinde med Knappenaals-Øine i et Barneansigt lagde sig i Veien for mig. Da hun ikke vilde flytte sig, maatte jeg bede Betjenten om at tage Affaire. Ovenfor Veien stod et gammelt Brunsteens-Huus. Omkring et Tagvindue var der en sværm af de flyvende InsektÆdere, der gaae under Betegnelsen Flagermuus, af Ordenen Chiroptera. Deres super-soniske Skrig satte mit Uhr istaae.

Paa een af vore natlige Promenader kom Baronessen og jeg ud for en curieus Oplevelse. Ved Foden af Nordmuren fandt vi en forulykket Flagermuus som kaldte os ved Navn. Dens Stemme var som et Barns. Vi gave den Fred. Dens Skrig gjaldede dog stadig i mine Øren da jeg var gaaet til Ro. Min Vertinde var kort for Hovedet, efter Middagen trak hun sig tilbage med en suurmulende Und- 
skyldning. Det havde Noget at gjøre med Murene: de Hulrum, den smuldrende Fuge-Masse har efterladt, lade sig ikke beboe af Svaler. Paa Klokke-Loftet vaagne Flagermuusene. Paa min Kind er opstaaet et vædskende Saar. Min Graad er stilnet heelt af. Jeg føler Intet, men tænder ligegyldigt en Cigaret.

Huus-Hovmesteren meddeeler mig at een af de lokale Partisaner, en Høit decoreret Krigshelt forøvrigt, har forsøgt at trænge ind $i$ Slottets Garage-Anlæg, angivelig for at sabotere min Vogn. Rettergangen har funden Sted. Baronessen sender et Condolence-Telegram til de Efterladte. Til Middag spise vi Hjerne-Stuvning. Jeg kysser ømt min Venindes hvælvede Laar. Hun leer hæst. Blæsten har givet hende en let Forkjølelse.

Paa mine Toure i Landskabet har jeg stundom mødt en ung Qvinde som bar omkring paa et stort Stue-Uhr. Jeg har undret mig en Deel over hende, men har fundet det bedst ikke at omtale hende for Baronessen. Der er ingen Grund til at skabe unødig Bekymring. Jeg kysser hende paa Halsen. Jeg mærker Gulvet gynge under mine Fødder og kommer i Tanke om Advarslerne vedrørende EtageAdskillelsernes Forfatning. Baronessens Skjønhed er mig dyrebar. Jeg snitter et Hjerte i hendes Side.

Min Venindes Skjønheds-Plet fylder mig med uforklarligt Veemod. Den hviiner som Spædbørn i Pine. Flagermuusenes pludselige Apathie bekymrer mig naturligviis. Inat græd jeg slet ikke, jeg betragtede min Elskedes besværede Veir-Trækning. Hun holder ikke længe nu.

Frokosten sprang jeg over. Baronessen staaer ikke op længer, Lægen var her og bad mig om at sætte mig ned da vi talte sammen. Hans Ansigt skreeg som et Barns, Knappenaals-Øinene græd salte Taarer ned i mit Uhr saa det gik istaae. Han fortsatte paa sin Runde; han skulde tilsee en ung Qvinde som var bleven kjørt ned lige udenfor dette Huuses Mure. En saare gaadefuld Sag. Man formode at Partisanerne have havt en Finger med i Spillet. Efterat jeg har indstillet mine smaae Ride- og Spadsere-Toure i Nabolaget faaer jeg alle Informationer paa anden Haand. Sagen har fyldt mig med Uro. Skjøndt jeg hver Dag holder Udkik, har jeg endnu ikke faaet Svaler isigte. Det Saar, jeg havde paa Kinden, er atter forsvundet. Ingen har bemærket det. Det er ogsaa bedst saadan. Gartneren siger at min Vogn snart vil være klar igjen. Jeg stiller paa mit døde Uhr.

Yderst i Syns-Feltet svirre sort Flagermuus omkring, deres Skrig super-soniske, deres Taushed et Eccho fra en endnu ikke ganske svunden Fortid.
I Huusets Ydermure smuldrer Fuge-Massen, forstøver og flyver bort. Ingen Svale har endnu indfunden sig.

Færdsels-Politiet har endelig ryddet Veien.

Et Barn græder idet jeg trækker mit Uhr op. En Dødning stirrer mod mig fra Uhr-Skiven. Jeg smiler discreet. 